\title{
Changes in the Shape of the River-Bed over a Period of Time at the Base of the Vistula River before Cracow**
}

\section{Introduction}

Rivers belong to the most important factors changing the surface of the Earth. Their activity can be gradual and not visible or, on the contrary, extremely spectacular. Yet, apart from the manner how water interferes with the environment, it is necessary to determine emerging changes $[1,3]$. Such a necessity is a result of the need of preparing accurate and updated maps, both cadastral and those, ordered for projects.

Although the erosion process, taking part in the surroundings of the water concern equally the whole cross-section of the river, yet these which take place on the plane are more important [2]. It comes from the fact, that within surveying works (especially of surveying-legal types) it is important to know how a river "travels" on the bottom of its valley (creating changes) and how these changes can influence the shapes of the cadastral boundaries and also on the contours of land use and the contours of soil classes.

A sight of the surface of terrain are of course various kinds of mapping works. They carry full and detailed knowledge about the landscape, which part are rivers, in four dimensions one $(x, y, z, t)^{1}$ [4]. They describe the changes caused by rivers. Regularly updated let an analysis of river-bed changes which took part in space, within the period of time.

* AGH University of Science and Technology, Faculty of Mining Surveying and Environmental Engineering, Department of Geomatics, Krakow, Poland

** This work has been made within scientific research program of Department of Geomatics no. 11.11.150.006

$1 x, y, z$ - mean "spatial coordinates", while $t$ - denotes "time" (authors' remark). 


\section{An Influence of Changes of the Shape of a River-Bed on Cadastre}

Surveying and Mapping Law [8] obliges surveyors to permanently update of base maps, being the results of all surveying works. Changes in river-beds have a particular influence on such an important contents of base maps as cadastral layer is.

Such updating is connected with changes of boundaries of river banks and influences on changes of shapes of:

1) Cadastral boundaries in connection with displacing the range of real estate ownership [3], according to regulations of Water Law [9], which says that: "if inner, flowing water will permanently occupy a land being not property of owner of this water, a consequence of this event is that this land becomes a property of owner of water".

2) Contours of land use and contours of soil classes resulting from definitions of lands under flowing waters, according to the Order in case of Lands and Buildings register [7].

\section{Factors Influencing Changes in the Shape of a River-Bed}

In the opinion of geomorphologist, rivers belong to the most important outside factors, transforming the surface of the Earth [6]. Changes, which can take place at river surroundings can be caused both by the activity of water and also by antropogenic factors.

The river itself can influence its surroundings in two ways. Creating its elements through moving rock materials or destroy them by the erosion process. In any case, influence on the shape of river-bed is equally strong. Objects of destroying are at the bottom of river and its banks. This activity, although at different levels, can take place at all parts of the river flow. Processes, taking place as a result of erosion of a river are shown in table 1 .

Creative activity of any river is based upon on the fact that a river transports rock material, which can be timely deposited, or permanently collected in the river-bed or outside of it, as a result of diminishing transport force [5].

Accumulative activity of rivers can take place along the whole distance of the river-bed and leads to various types of sediments. Yet, most often one can observe this activity when water level is raised or when water ability of to transport diminishes. 
Table 1. River erosion

\begin{tabular}{|c|c|c|}
\hline River section & Type of erosion & Result of river activity \\
\hline \multirow{4}{*}{ upper (source) } & subterranean & $\begin{array}{l}\text { river cuts into river-bed through damaging it by transporting } \\
\text { rock material }\end{array}$ \\
\hline & backward & $\begin{array}{l}\text { moving back source of river toward a watershed can cause } \\
\text { joining two rivers or the moving back of waterfalls }\end{array}$ \\
\hline & side (waterside) & $\begin{array}{l}\text { undermining action of water of river banks; leads to } \\
\text { damaging of banks }\end{array}$ \\
\hline & bottom & $\begin{array}{c}\text { channelling of bottom of river leads to creating flood-land } \\
\text { terraces }\end{array}$ \\
\hline \multirow{2}{*}{ middle } & side & $\begin{array}{l}\text { undermining action of water of river banks; leads to } \\
\text { damaging of banks, creating meanders and old river-beds }\end{array}$ \\
\hline & bottom & $\begin{array}{c}\text { channelling of bottom of river leads to creating flood-land } \\
\text { terraces }\end{array}$ \\
\hline lower (mouth) & & erosion is usually not visible \\
\hline
\end{tabular}

Source: own work based upon [5] and [6]

As a result of the diminishing accumulation potential of a river is becoming alluvial cones, deltas, and alluvial plains. In time freshets, when water does not come out of the river-bed, rock material is moved and deposited in the shape of sandy backwater (sandbanks) that is sandy or gravelly islands. They can be located centrally in the river or on the side of the river-bed. Whereas a river overflows, a deposition takes place in the part of the river-bed and contributes to form river mud.

Additionally, the permanent aspiration of people to subordinate the natural environmental, causes antropogenic changes to the river-bed. In order to take control of rivers one can try to regulate them and built up in its neighbourhood building structures, which have to facilitate human being domination over nature. Most of them cause changes in the river-bed in the manner to be convenient for people or create river sediments in front of them.

Apart from such restrictive regulations of rivers, there are other methods to restrain them. They lead for such forming of river-bed, which diminishes the risk of becoming an un planned phenomena along its course. It is the best case, when a regulated out river-bed fits with water natural activity and determines in the field such situation which could take place after passing higher water. 


\section{Analysis of Changes of Shape of the Vistula River-Bed}

The object of this research has been $13.5 \mathrm{~km}$ long section of the Vistula river-bed, located west of Cracow. Along with this section of the river runs administrative border between Czernichów and Liszki communes, and the Skawina commune. These three communes are located within the krakowski district.

The process of controlling the river-bed course has been done on the basis of cadastral maps coming from the time of establishing grounds register (early seventies of the XXth century) on the basis of the Decree from 1955 and aerial photos, and ortophotomaps made upon flying time in April 2009.

At first, cadastral maps in digital format prepared in raster model in the scale of 1:2000 have been taken from the district surveying documentation centre. Each of these maps has been made for a cadastral unit. There have been also taken coordinates of network points, given in the state coordinates system "1965". They were used during establishing grounds register. Network points of known coordinates have been taken as control points for the transformation of scanned maps. Contemporary bank lines of the river can be found on cadastral maps. They are contours of land use called "flowing waters", and comprises area of all parcels being under the water.

In order to verify data contained on cadastral maps, photogrammetric data coming from the Country Documentation Surveying Centre have been used. They are aerial photos made during modernization and updating databases of Land Parcels Identification System (LPIS). The river bank boundary has been determined by photogrammetric methods. Measurement has been done on photos using the stereoscopic method. According to Water Law [9], the upper part of the slope, as exists along the whole of analysis the river-bed, has been taken as the river bank boundary.

A comparison of two river bank boundaries at the whole inspected section gave unexpected results. It turned out that the river "works" all the time and changes its river-bed, despite the fact that these activities are not visible every day. This comparison (green colour: old river bank boundary, red colour: current river bank boundary) - is showed on figures 1-3. Considering a lot of researched materials, these figures show only these sections of the river-bed where changes are the biggest.

Because the Vistula River, west of Cracow is also an administrative border between mentioned earlier communes, discussed sections of the river-bed are described by names of cadastral units adjoining themselves in the place showed on figures 1-3. All presented fragments of maps are oriented north. For their better interpretation, corresponding them pieces of ortophotomaps, have also be put. 


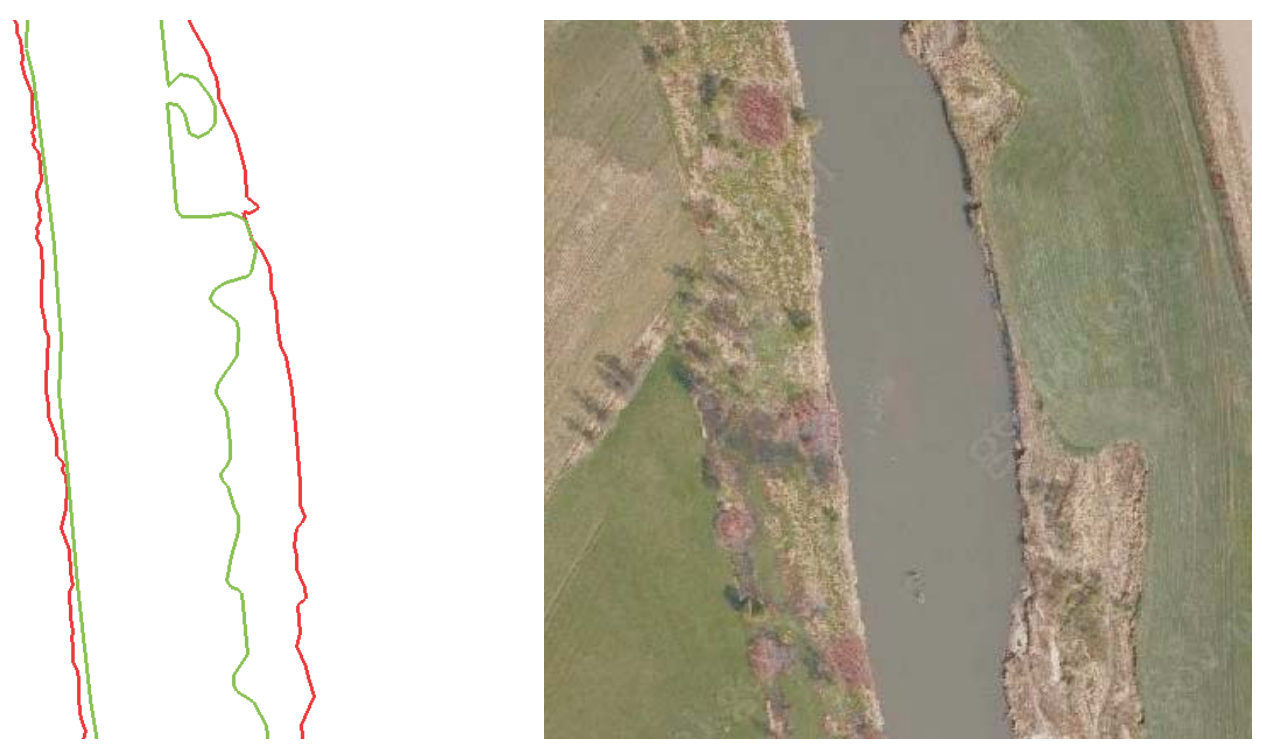

Fig. 1. Change of shape of the river-bed in years 1977-2009, section between cadastral units Czernichów and Pozowice Source: [10]
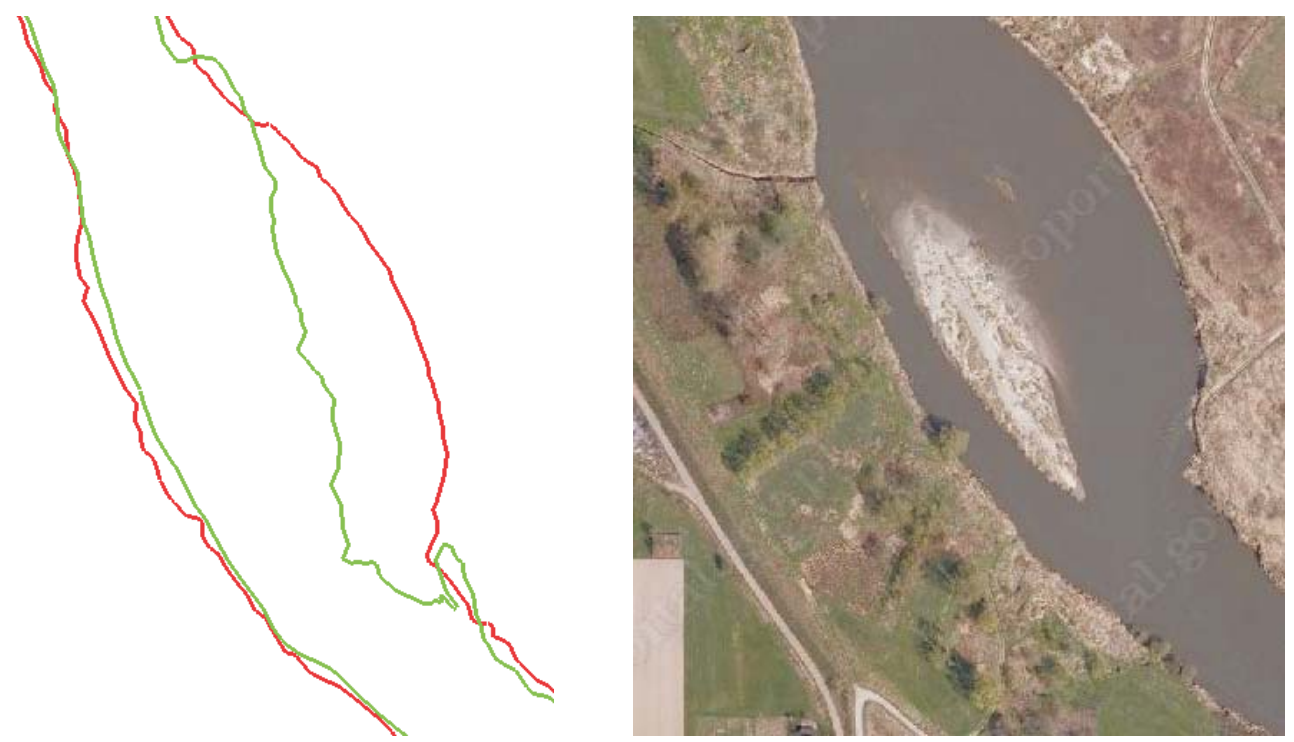

Fig. 2. Change of shape of the river-bed in years 1977-2009, section between cadastral units Wołowice and Pozowice

Source: [10] 

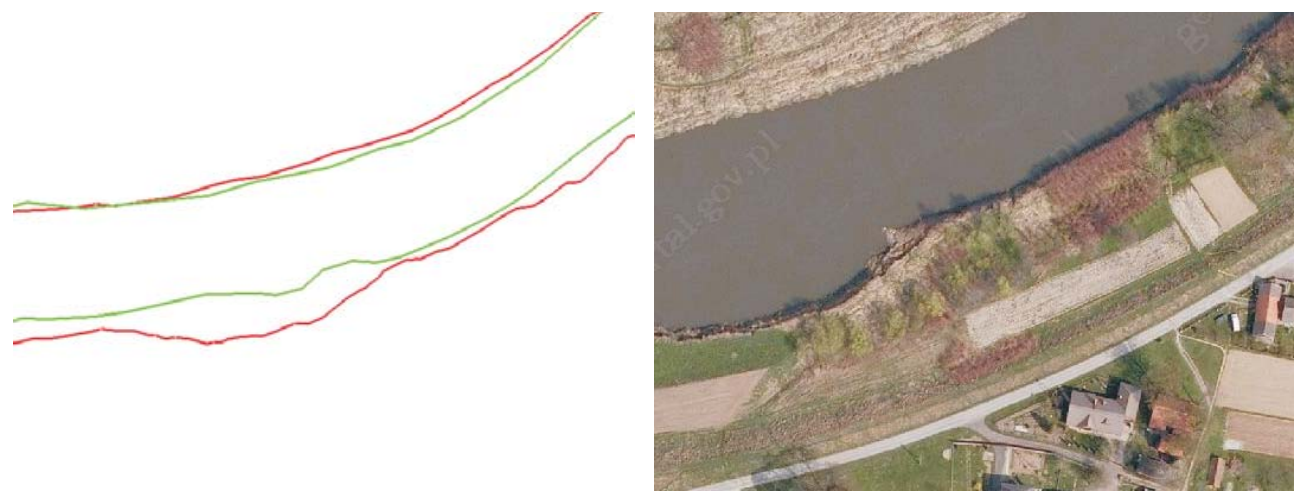

Fig. 3. Change of shape of the river-bed in years 1977-2009, section between cadastral units Czernichów and Pozowice

Source: [10]

Section of the river between Czernichów and Pozowice, being showed as the first (Fig. 1), is located hard attacking left bank. It is visible big extension of the river-bed in this place. Observed differences reach even 30 meters. The right side of the river bank is almost without any changes.. Changes, visible, on the west river bank, are probably the result of surveyor interpretation.

The following example is a section of river-bed, located within the Wołowice and Pozowice cadastral units. The showed situation (Fig. 2), is a part of the next meander. Water undermines here the left bank of the river much more, causing more bigger (reaching 50 meters) changes in the bank line. The opposite line bank has almost not been modified. Yet, it does not mean that no changes have been remarked. Of course they were, although not so big as it took place by left bank of river. One should say, that stream did not have so big force as water flowing near the east slope. That is the reason why an island is here. Water, flowing around it with the stronger force, hits the east side of the river-bed.

The last example (Fig. 3), is a part of the river between two, earlier discussed meanders. The river flows here from west to east. The water hits stronger at the right river bank. It is clearly visible as the line of bank river "invaded" inside a land, causing considerably landslipe of slope, has just been creating right bank.

As a result of above-mentioned changes, it is necessary to also change the course of contours of land use and soil classes.

Because changes in the river bad can prove so big, that as a result of them the range of ownership right can also be changed, it is necessary to change the courses of the cadastral boundaries. For this purpose, ortophotomaps have been used, in relation with former cadastral maps. Figure 4 shows such an application and comparison between river boundaries by means of Geoportal data [10]. 
a)

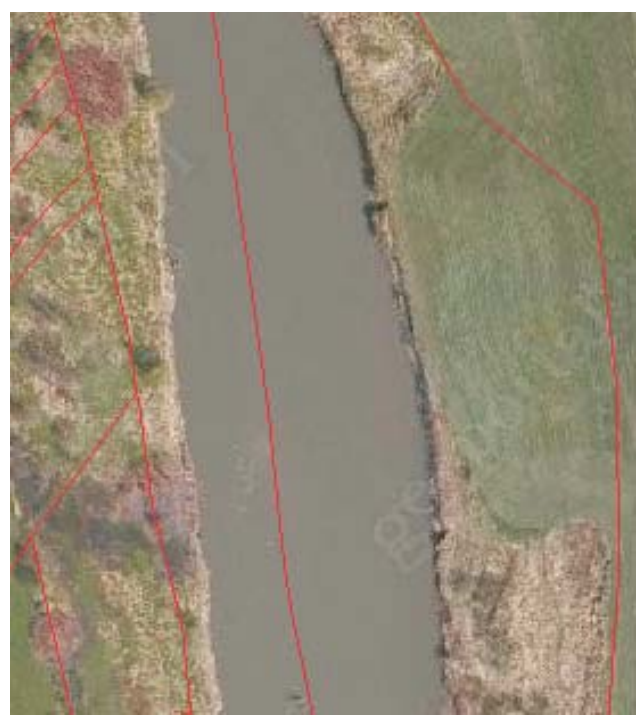

b)

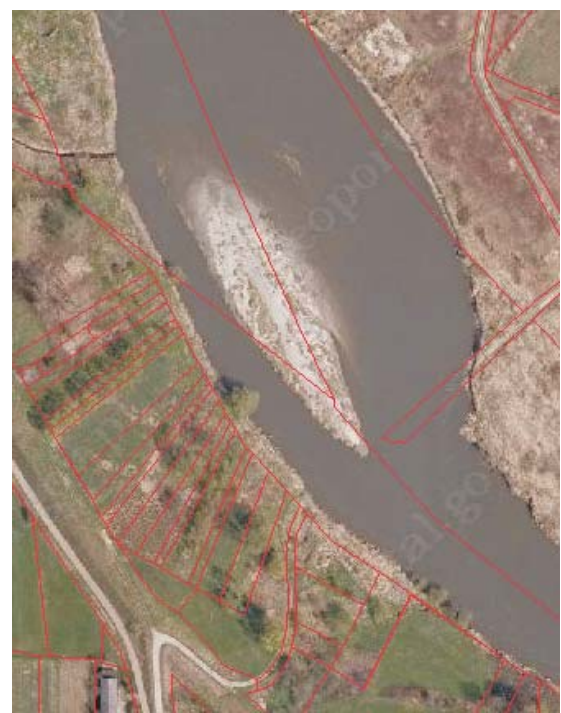

c)

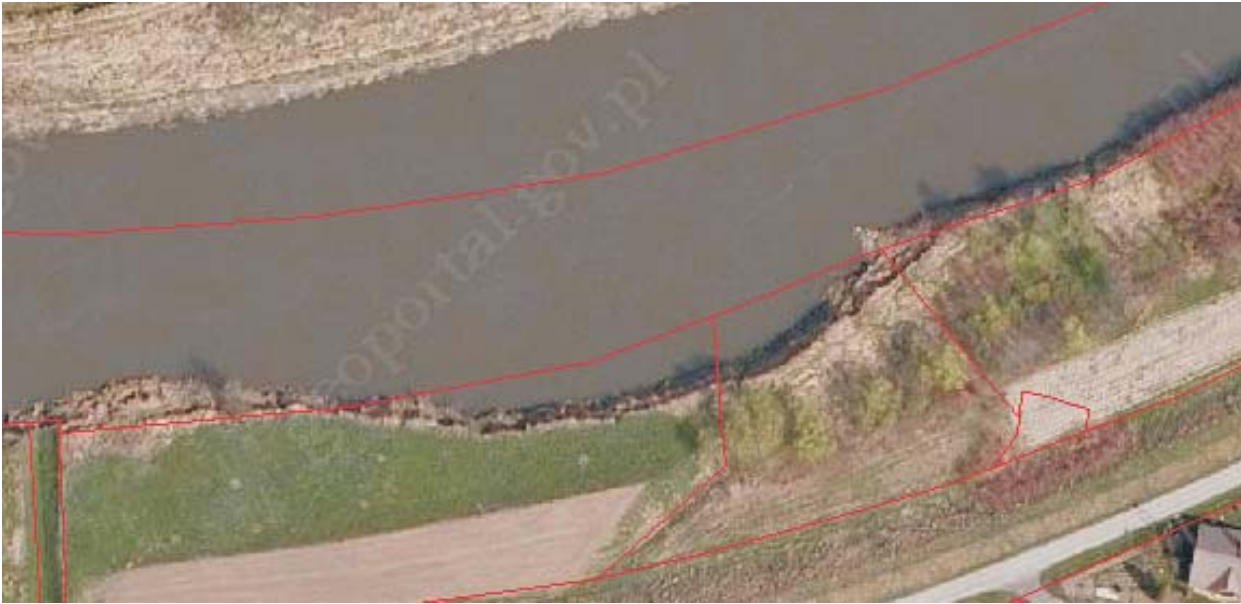

Fig. 4. Comparison between the current river-bed boundary with data boundaries coming from the grounds and buildings register: a) in relation with figure 1 ; b) in relation with figure $2 ; \mathrm{c}$ ) in relation with figure 3

Source: [10]

In two from three discussed cases (Fig. 4b, c) waters of the river have constantly occupied adjoining lands. So, according to Water Law [9] the range of ownership right had to be also moved. In case $4 \mathrm{~b}$, water rushed in parcels located in Wołowice, but in case $4 \mathrm{c}$ - water took part of the parcel located in Pozowice. Thus, the Vistula River diminished area of the parcel in Wołowice about $3.5 \%$ and the parcel located in Pozowice about almost $20 \%$. 


\section{Conclusion}

To summarize, authors want to express the following remarks.

- Flowing superficial waters, especially big rivers, can influence the entire environment. It is very important for surveyors, that changes in the river-bed can also cause changes in cadastral data.

- As a consequence of changes in the river-bed it will probably be necessary to modify courses of parcel boundaries and also courses of land use and soil classes.

- There are possible not only changes in ownership rights but also its complete transfer without change course of parcel boundaries - in the case when water will permanently occupy the whole cadastral parcel.

\section{References}

[1] Bieda A.: Weryfikacja granic administracyjnych prowadzonych wzdtuż rzek $w$ aspekcie aktualizacji katastru. AGH, Kraków 2011 (Ph.D. thesis, unpublished).

[2] Bieda A.: River bank boundary determination. Geomatics and Environmental Engineering (AGH-UST quarterly), vol. 4, no. 2, 2010, pp. 15-22.

[3] Hycner R.: Podstawy katastru. Uczelniane Wydawnictwa Naukowo-Dydaktyczne AGH, Kraków 2004.

[4] Lech-Turaj B., Noga K.: Zmiany w krajobrazie bieszczadzkich wsi na przykładzie gminy Baligród. Infrastruktura i Ekologia Terenów Wiejskich, nr 3, 2011, pp. 227-233.

[5] Klimaszewski M.: Geomorfologia. PWN, Warszawa 1981.

[6] Migoń P.: Geomorfologia. Wydawnictwo Naukowe PWN, Warszawa 2006.

[7] Rozporzadzenie Ministra Rozwoju Regionalnego i Budownictwa z 29 marca 2001 r. w sprawie ewidencji gruntów i budynków. Dz. U. Nr 38, poz. 454.

[8] Ustawa z dnia 17 maja 1989 r. - Prawo geodezyjne i kartograficzne. Dz. U. Nr 30, poz. 163 z późn. zm.

[9] Ustawa z dnia 18 lipca 2001 r. - Prawo wodne. Dz. U. Nr 115, poz. 1229 z późn. zm.

[10] Geoportal, [on-line:] http://geoportal.gov.pl. 